\title{
Histone lysine methylation and congenital heart disease: From bench to bedside (Review)
}

\author{
XIN YI ${ }^{1-3}$, XUEJUN JIANG ${ }^{1-3}$, XIAOYAN LI ${ }^{1-3}$ and DING-SHENG JIANG ${ }^{4-6}$ \\ ${ }^{1}$ Department of Cardiology, Renmin Hospital of Wuhan University; ${ }^{2}$ Cardiovascular Research Institute, Wuhan University; \\ ${ }^{3}$ Hubei Key Laboratory of Cardiology, Wuhan, Hubei 430060; ${ }^{4}$ Division of Cardiothoracic and Vascular Surgery, \\ ${ }^{5}$ Key Laboratory of Organ Transplantation, Ministry of Education, ${ }^{6}$ Key Laboratory of Organ Transplantation, \\ Ministry of Health, Tongji Hospital, Tongji Medical College, Huazhong University \\ of Science and Technology, Wuhan, Hubei 430030, P.R. China
}

Received August 15, 2016; Accepted August 21, 2017

DOI: 10.3892/ijmm.2017.3115

\begin{abstract}
Histone post-translational modifications (PTM) as one of the key epigenetic regulatory mechanisms that plays critical role in various biological processes, including regulating chromatin structure dynamics and gene expression. Histone lysine methyltransferase contributes to the establishment and maintenance of differential histone methylation status, which can recognize histone methylated sites and build an association between these modifications and their downstream processes. Recently, it was found that abnormalities in the histone lysine methylation level or pattern may lead to the occurrence of many types of cardiovascular diseases, such as congenital heart disease (CHD). In order to provide new theoretical basis and targets for the treatment of CHD from the view of developmental biology and genetics, this review discusses and elaborates on the association between histone lysine methylation modifications and CHD.
\end{abstract}

\section{Contents}

1. Introduction

2. Histone methylation

3. Histone lysine methylation and heart development

Correspondence to: Dr Xuejun Jiang, Department of Cardiology, Renmin Hospital of Wuhan University, 238 Jiefang Road, Wuhan, Hubei 430060, P.R. China

E-mail: xjjiang@whu.edu.cn

Dr Ding-Sheng Jiang, Division of Cardiothoracic and Vascular Surgery, Tongji Hospital, Tongji Medical College, Huazhong University of Science and Technology, 1095 Jiefang Avenue, Wuhan, Hubei 430030, P.R. China

E-mail: jds@tjh.tjmu.edu.cn

Key words: histone lysine methylation, histone methyltransferase, congenital heart disease, epigenetic modifications
4. Related enzymes of histone lysine methylation and congenital heart disease

5. Conclusion and prospection

\section{Introduction}

Congenital heart disease (CHD) involves the anatomical structure abnormality caused by the formation of obstacles or the abnormal development of the heart and great vessels during the period of embryonic development, or a group of congenital malformations with actual or potential influence on heart function arising from the open tunnels which should have selfclosed after childbirth. CHD mostly occurs during 2-8 weeks after impregnation, and it is the most common cardiovascular malformation affecting children; it severely affects the health of infants and young children (1-4). At present, CHD is regarded as a multigene disease influenced by the environment and heredity; however, the pathogenesis of the disease and the underlying molecular mechanisms and interations between genes remain unclear (5-8). Heart development is a very complex process, involving the expression of numerous genes at specific time points in the process of embryonic development, and it is regulated by many transcription factors $(9,10)$. The realization of this process is not only determined by gene sequences, but is also largely generated by the transformation of epigenetics. In addition, an increasing number of studies have found that children with CHD have an extremely low occurrence rate of gene mutation, which can only explain a small number of CHD cases, as there is no pathogenic gene transformation for the majority of CHD cases (11-13). Some recent studies have found that 'epigenetics' may very likely participate or play an important role in the occurrence of CHD (14-16).

Epigenetics suggests that DNA sequence undergoes no transformation, but the gene expression occurs by heritable transformation, which is the other heritable material transformations in the cells apart from the heritage information and with stable heredity in the process of cell development and proliferation (17-19). Epigenetics is mainly the reversible and heritable transformation of gene function with the DNA sequences of the nucleus unchanged, and these transformations include DNA 
modifications (such as methylation), various kinds of histone modifications (such as methylation, acetylation, ubiquitination and phosphorylation), chromatin remodeling, non-encoding RNA regulation (20-26). In the field of 'epigenetics', by transforming the chromatin structure with the help of related enzymes and interacting with other regulator protein, histone modifications regulate gene expression, and influence occurrence and development of diseases, which is also known as 'the second heritage code', mainly including methylation, acetylation, phosphorylation, ubiquitin, adenosine, small ubiquitin related modification, ADP ribosylation and proline isomerization $(21,27,28)$. Histone methylation is one of the most common histone modifications, and mainly includes arginine methylation and lysine methylation (29-31). Comparatively speaking, histone methylation modification transforms loosen or agglutination state of chromatin mainly through influencing the affinity of histone and DNA, regulates gene expression by influencing the affinity of other transcription factors and structural gene promoters. Thus, it can be seen that histone methylation modification has the gene expression regulatory function similar to the DNA genetic code, and plays an important role in the process of growth and development (32-34).

In recent years, studies have shown that histone lysine methylation is not only closely related to tumor occurrence and development, developmental defects, senile dementia, cardiac hypertrophy and other clinical diseases, but also participates in the occurrence of CHD, influencing the development of heart structure and CHD candidate gene expression (35-45). For this reason, this review aims to summarize the new progress of CHD epigenetic mechanism research from the aspect of histone lysine methylation modification, in order to provide a new scientific basis for the prevention and treatment of CHD.

\section{Histone methylation}

Histone methylation involves the methylation occurring at histone $\mathrm{H} 3$ and the $\mathrm{N}$-terminal of $\mathrm{H} 4$ arginine (Arg) or lysine (Lys) residues, catalyzed by histone methyltransferase. The function of histone methylation is mainly reflected in heterochromatin forming, genomic imprinting, $\mathrm{X}$ chromosome inactivation and transcriptional control (46-52). Apart from histone methyltransferase, the histone demethylase is also found $(53,54)$. At first, it was considered that the histone methylation effect was stable and irreversible; however, the existence of methyltransferase renders the process of histone methylation more dynamical.

Modification sites of histone methylation. Histone methylation can occur on of Lys and Arg histone residues. Lysine residues can be single, double and triple methylated, while arginine residues can be single and double methylated (55-57). This varying degree of methylation largely increases the complexity of histone modifications and regulator gene expressions $(29,58)$. Methylation action sites are in the $\mathrm{N}$ atoms at the side chains of Lys and Arg. Lys locus 4, 9, 27, 36 and 79 of histone H3 (H3K4, H3K9, H3K27, H3K36 and H3K79), Lys locus 20 of histone H4 (H4K20), Arg locus 2, 17, 26 of histone H3 (H3R2, H3R17 and H3R26) and Arg locus 3 of histone H4 (H4R3) are the common loci of methylation (Fig. 1). Studies have shown that histone Arg methylation is a comparatively dynamical mark, and is related to gene activation; however, Arg methylation lacking $\mathrm{H} 3$ and H4 is related to gene silencing (59-61). On the contrary, Lys methylation seems to be a stable mark of gene expression regulation. For example, $\mathrm{H} 3 \mathrm{~K} 4$ methylation is related to gene activation, while $\mathrm{H} 3 \mathrm{~K} 9$ and $\mathrm{H} 3 \mathrm{~K} 27$ methylation are related to gene silencing $(38,62-66)$. In addition, H4K20 methylation is related to gene silencing, $\mathrm{H} 3 \mathrm{~K} 36$ and $\mathrm{H} 3 \mathrm{~K} 79$ are related to gene activation (67-72).

Related enzymes of histone methylation. Arginine methylation occurs at the equal locus of histone H3R2/R17/R26 and H4R3, and plays a promoting effect on gene expression (60). When the methylation process occurs, histone arginine methyltransferase or protein arginine methyltransferase (PRMT), as the collaborative activity factor, is recruited into the promoter region of the target gene and thus activates gene expression (73-75). The PRMT of catalyzing histone arginine methyltransferase includes two categories: the first type of PRMT being catalyzed to form single methylation arginine and unsymmetrical double methylation arginine, and the second type of PRMT being catalyzed to form single methylation arginine and symmetrical double methylation arginine (76,77). The family of PRMT includes PRMTl, PRMT3, RMTI/HMT, PRMT4/CAMRl and PRMT5. $\mathrm{K} 4, \mathrm{~K} 9, \mathrm{~K} 27, \mathrm{~K} 36, \mathrm{~K} 79$ of histone $\mathrm{H} 3$ and $\mathrm{K} 20$ of $\mathrm{H} 4$ all can be methylated. The methylation level is regulated and executed by a type of methyltransferase with SET structural domain with highly conserved nucleus and the pre-SET and post-SET structural domain with abundant cysteine sequence $(31,78,79)$. The denomination of SET structural domain is constituted with 3 initial letters of 3 genes from expressing SET structural domain found at the earliest, which are $\mathrm{Su}(\mathrm{var}) 3-9, \mathrm{E}(\mathrm{z})$ and Trx (80). Furthermore, histone demethylase can catalyze histone lysine to demethylation, and then affect the level of methylation. At present, the demethylase of histone mainly has two types: lysine specific demethylase (LSD1) and Jmjc domain-containing histone demethylase (JHDM) $(81,82)$.

\section{Histone lysine methylation and heart development}

Epigenetic modification, including methylation and acetylization plays an important role in the regulation of gene expression. Studies have indicated that histone methylation can reduce or increase its affinity for charged DNA, loosen or tighten the chromatin structure to affect the accessibility and interactions between transcriptional factors and DNA templates, ultimately promote or inhibit gene expression $(83,84)$. Recent evidence supports a prominent role for histone methylation in normal and aberrant heart development (85-87). A recent study demonstrated that changes in histone methylation levels in histone $\mathrm{H} 3$ that binds with critical promoter parts of the ssTnI gene can cause the corresponding changes in ssTnI gene expression, which indicated that histone methylation was involved in the regulation of myofibril gene expression in the heart during development (88). Additionally, Hand 2 and Irx4 transcription factors have been shown to be reduced in SMYD1-deficient mice, suggesting that SMYD1-mediated histone methylation is necessary for the expression of these essential cardiac transcription factors (89). Hence, these findings illustrate the pervasive roles of histone methylation in the process of heart development. 


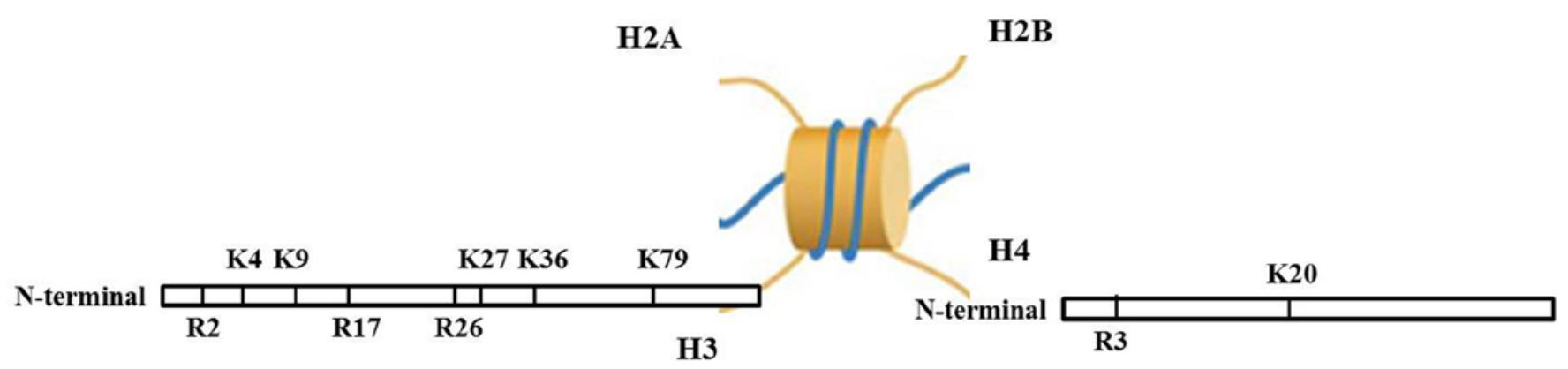

Figure 1. The common methylation action sites in $\mathrm{H} 3$ and $\mathrm{H} 4$.

\section{Related enzymes of histone lysine methylation and congenital heart disease}

CHD is the most common type of birth defect, manifesting as obstacles in the process of embryonic heart or blood vessel development, which may result in the morphology, structure, function and metabolic abnormalities of heart and blood vessels $(2,3,5)$. According to the statistics, CHD has become the first reason for birth defects and the main cause of perinatal death and death in children (2). The causes of CHD are not yet completely clear; however, most scholars consider that many types of CHD are caused by a single gene mutation and chromosome aberration, and most types of CHD belong to complex genetic diseases, which are caused by the interaction between genetic factors and environmental factors $(90,91)$. Studies have shown that histone lysine methylation modification as part of the epigenetic regulation, is involved in the development of heart and blood vessels, which is also one of the causes of CHD $(92,93)$. The level of histone lysine methylation is determined by the balance of histone methylation and demethylation, which is a process by which methyl groups are transferred onto or removed from the amino acids of histone proteins. Histone methyltransferase and histone demethylase catalyze histone methylation and demethylation, respectively. In most cases, under the action of the methylation and demethylation, the histone tails relax or surround, which can loosen or inhibit DNA of transcription factors so as to turn the genes in DNA 'off' and 'on', resulting in the normal or aberrant expression of related genes and leading to abnormal heart development. To understand the research progress of histone lysine methylation and CHD, we summarize the known histone lysine modifying enzymes which regulates CHD in Table I.

\section{H3K4 methylation and CHD}

Trithotax group $(\operatorname{Tr} x G)$ proteins. During heart development, several cardiac progenitor pools give rise to diverse cell lineages, such as cardiomyocytes, vascular smooth muscle cells, fibroblasts that form the connective tissues and endothelial cells of the endocardium. The heart expresses many epigenetic factors, including both histone modifying proteins and chromatin remodelers. Among the epigenetic factors, TrxG proteins are special family of chromatin factors that regulate developmental gene expression in the heart (94). TrxG proteins function in multi-subunit complexes, three TrxG complexes, the MLL complex, the BRM/BAF complex and a supercomplex, and have been purified in mammalian cells (95). TrxG proteins are evolutionarily conserved $\mathrm{H} 3 \mathrm{~K} 4$ methyltransferases that maintain the transactivation states of lineage-specific genes during embryonic development. Multiple TrxG genes are normally expressed in the mouse heart. Due to the essential function of TrxG genes, constitutive knockouts of key TrxG genes often result in lethality during early embryogenesis before cardiac phenotypes can be analyzed. The differentiation of mouse embryonic stem cells (ESCs) toward mesodermal and endodermal lineages is severely altered and, in particular, the cardiac lineage differentiation of ESCs is completely abolished in the absence of MLL2, a TrxG member. Moreover, the expression of core cardiac transcription factors and the levels of $\mathrm{H} 3 \mathrm{~K} 4$ trimethylation of these cardiac-specific promoters are significantly decreased by the loss of MLL2 (96). Taken together, these results reveal a critical role for MLL2 in the proliferation and cardiac lineage differentiation of mouse ESCs, and provide critical insight not only into the novel role of the TrxG protein in cardiac development, but also into their clinical significance in related $\mathrm{CHD}$.

SMYDs. SET and myeloid, nervy and DEAF-1 (MYND) domain-containing proteins (SMYDs), including SMYD1-5, have two functional protein domains, SET (mediates histone lysine methylation activity) and MYND (mediates the proteinprotein interaction and binds to DNA motifs) domains (80). SET-MYND-domain 1 (SMYD1/BOP) encodes an evolutionary conserved histone methyltransferase containing a split SET domain interrupted by a MYND domain, which includes two members SMYD1a and SMYD1b, can catalyze H3K4 methylation (97). The expression of SMYD1 is restricted to skeletal and cardiac muscles in humans, fish, chickens and mice. There is evidence to indicate that SMYD1 plays important roles in cardiac differentiation, development and function (98). The global knockdown of SMYD1a and SMYD1b in zebrafish has been shown to result in the disruption of myofibril formation and an absence of beating of the heart. Molecular and cellular experiments showed that myofibers in embryos in which SMYD1 was knocked down appeared as immature myofibers with centrally located nuclei and disorganized myofibrils, indicating that SMYD1 played a critical role in myofibers maturation and contraction (97). Conventional null SMYD1 mice die in utero around embryonic day 10.5 (E10.5) due to heart defects, including disrupted maturation of ventricular cardiomyocytes and malformation of the right ventricle (99). However, Diehl et al recently reported that SET and MYND domain containing 2 (SMYD2), is capable of H3K4 methylation when bound to Hsp90a and acts on non-histone targets by 
Table I. Known histone lysine modifying enzymes involved in congenital heart diseases.

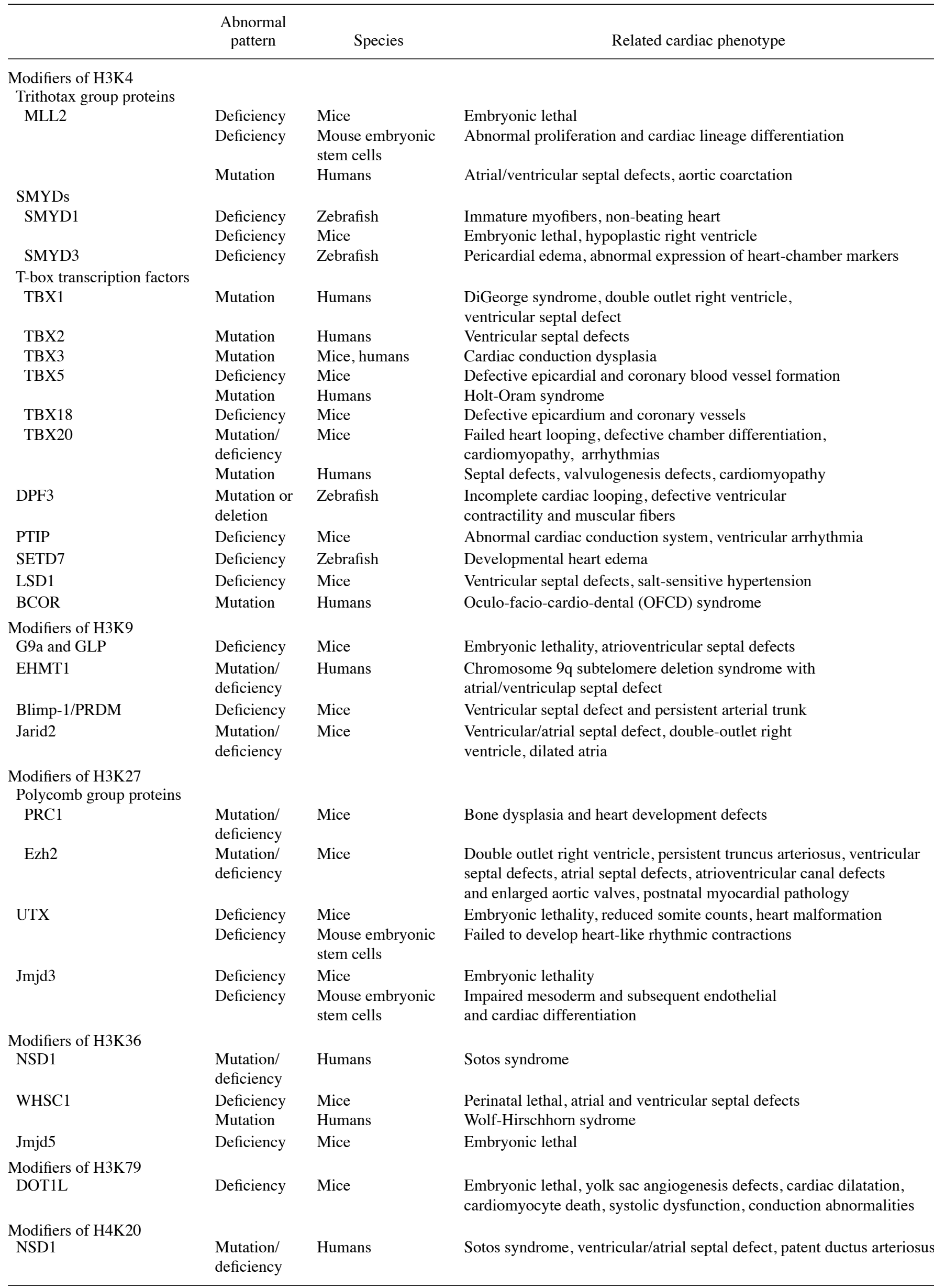


inhibiting the functional activity of p53 via methylation of p53, lysine 370 , which was differentially expressed during cardiac development with highest expression in the neonatal heart (100). To elucidate the functional role of SMYD2 in the heart, they generated knockout mice harboring a cardiomyocyte-specific deletion of SMYD2 and performed histological, functional and molecular experiments. Unexpectedly, cardiac deletion of SMYD2 was dispensable for proper morphological and functional development of the murine heart (100). H3K4 methyltransferase SMYD3 is highly expressed within developing zebrafish heart and knockdown of it led to severe defects such as pericardial edema and abnormal expression of three heart-chamber markers in cardiac morphogenesis (101). These results indicate that SMYD3 plays an important role in heart development and its proper functioning is essential for normal heart morphogenesis during development.

T-box (TBX) transcription factors. TBX transcription factors share a highly conserved DNA-binding domain and play critical roles in embryonic development (102). Six members of TBX family (TBX1, TBX18 and TBX20 of the TBX1 subfamily, and TBX2, TBX3 and TBX5 of the TBX2 subfamily) are required for the cardiac morphogenesis in mammals (103). TBX1 interacts with $\mathrm{H} 3 \mathrm{~K} 4$ methyltransferase to enhance its H3K4 monomethylation status through T-box, regulates expression of related genes by epigenetic patterns (104). TBX1 mutation can lead to DiGeorge syndrome (DGS), which is the most common microdeletion syndrome, and is characterized by congenital cardiac, craniofacial and immune system abnormalities (105). Additionally, Pan et al reported that a novel heterozygous TBX1 mutation, p.Q277X, was identified in an index patient with double outlet right ventricle and ventricular septal defect (106). TBX2 gene is expressed in the myocardium of the atrioventricular canal, outflow tract and inflow tract and plays a critical role in heart chamber formation (107). The genomic deletion and duplication of TBX2 gene have been found to be associated with ventricular septal defects (108). The evolutionary conserved TBX3 gene encodes T-box transcription factors and locus forms a CTCF independent autonomous regulatory domain with multiple combinatorial regulatory elements, which plays crucial roles in the development and homeostasis of the cardiac conduction system in humans and mice (109). Previous studies have found that TBX5 is expressed in the proepicardial organ or septum transversum, which is required for the normal development of proepicardium/proepicardial organ cells, as well as proper epicardial formation and maturation (110). Additionally, TBX5 deficiency delays epicardiac cell attachment to the myocardium and impairs production of epicardial-derived cells and their migration into the myocardium, and results in abnormal coronary vasculogenesis and murine ischemic cardiomyopathy (111). Clinical studies have shown that Holt-Oram syndrome is caused by mutations in TBX5, which is a human inherited disorder and manifests as left pericardium agenesis and anomalous coronary arteries along with ventricular septal defects (112-114). These findings all demonstrate that TBX5 is essential for epicardial development in hearts and establishment of the coronary vasculature. Similar to TBX5, TBX18 is also highly expressed in proepicardial cells and proepicardium, TBX18-deficient proepicardium produces an epicardium and coronary vasculature with structural and functional defects, and that remodeling of the disorganized subepicardial plexus in TBX18-deficient hearts produced a mature coronary artery network with fewer distributing conduit vessels and smaller lumen profiles, which indicates that TBX18 plays critical role in coronary development (115). However, TBX20 is necessary in heart development by regulating cardiomyocyte proliferation and regional specification and formation of cardiac chambers and valves; TBX20 mutations in mice can result in the failure of heart looping, developmental arrest, and the lack of chamber differentiation, and loss of TBX20 in mice leads to cardiomyopathy with associated arrhythmias and death $(116,117)$. More seriously, mutations in human TBX20 result in cardiac malformations including septal defects, double outlet right ventricle and cardiomyopathy $(118,119)$. These findings provide novel insight into the molecular mechanism underlying CHD and suggest potential implications for the development of novel preventive and therapeutic strategies for CHD.

$D P F 3$. DPF3 is a member of the highly conserved $\mathrm{d} 4$ protein family, which is characterized by a double PHD finger in the C-terminal and has two splice variants DPF3a and DPF3b in human and mice (120). In the process of embryonic development, DPF3 is expressed both in heart and somites of mouse, chicken and zebrafish, which is important epigenetic regulation factor for heart and muscle development by associated with the BAF chromatin remodeling complex and binds methylated lysine residues of H3K4 (121). Previous studies have found that DPF3 mutation or deletion leads to incomplete cardiac looping, attenuated ventricular contractility and disassembled muscular fibers caused by the transcriptional deregulation of structural and regulatory proteins in the heart, which all demonstrate that DPF3 is responsible for cardiac development imbalance, ventricular septal defect and other cardiac disorders (121).

Pax transactivation domain interacting protein (PTIP). PTIP is an essential cofactor for H3K4me by KMT2C/D, which is encoded by the Paxip1 gene and is essential for embryonic development in mice and flies (122-124). As a critical component of the KMT2C/D complex, the loss of PTIP leads to reduced levels of H3K4me3 in whole embryos, ESCs and Drosophila larvae $(125,126)$. Stein et al demonstrated that temporal and tissue-specific deletion of PTIP reduces H3K4 methylation level and alters the transcriptional program in nondividing cardiomyocytes. It is suggested that a role for KMT2 complexes not just in establishing active chromatin domains but also in the maintenance of the differentiated state over time. Furthermore, the loss of PTIP-mediated H3K4me results in significant changes in the physiology of the cardiomyocytes, suggesting that PTIP deletion is the direct cause of premature ventricular beats, a harbinger of lethal ventricular arrhythmias in nondividing cardiomyocytes $(42,127)$.

SET domain containing protein 7 (SETD7). SETD7 also termed as SET7/9, is another type of histone lysine methyltransferase and only has SET domain for methyltransferase activity, but not MYND domain, which is initially discovered as a specific methyltransferase for nonmethylated H3K4. Tao et al found that the knockdown of SETD7 showed the defects in skeletal muscle formation and myofibril structures in a zebrafish developmental model (128). To examine the function of SETD7 in heart development, Kim et al firstly demonstrated that SETD7 was highly expressed in developing zebrafish heart and knockdown of it led to severe defects in cardiac morphogenesis such as developmental heart edema. 
Furthermore, the double knockdown of SMYD3 and SETD7 caused synergistic defects in heart development. Similar to the knockdown effect, the overexpression of SETD7 also caused the heart morphogenesis defects in zebrafish (85). These results indicate that the histone modifying enzyme, SETD7, plays an important role during heart development and its proper functioning is essential for normal heart morphogenesis during development.

Lysine-specific demethylase 1 (LSD1). LSD1 (also known as AOF2/KDM1A), is a member of a group of enzymes with lysine specific demethylase activity. LSD1 performs enzymatic activity toward di- and monomethyl H3K4 and H3K9 respectively; the specificity for H3K9 arises when LSD1 binds to the androgen receptor, resulting in a shift of its activity from H3K4 (129). LSD1 interacts with proteins mostly through the tower domain, an extended helical structure. Furthmore, there is evidence to indicate that LSD1-interacting proteins can regulate the activity and specificity of LSD1 in developmental processes $(130,131)$. Nicholson et al found that mice homozygous for a hypomorphic LSD1 allele exhibit a failure to survive after birth perinatally due to heart defects, with the majority of animals suffering from ventricular septal defects (132). Therefore, the above-mentioned studies thereby illuminate a novel role for LSD1 in the development of the mammalian heart.

$B C L-6$ corepressor (BCOR). It was found that $\mathrm{BCOR}$ inhibited gene transcription by interacting with BCL- 6 , and BCOR mutation resulted in abnormal activation of AP-2a, which was a key factor that mediated the differentiation of bone marrow mesenchymal stem cells (MSCs) (133). Fan et al also pointed out that BCOR recruited a histone demethylase JHDM1B to the target gene promoter, resulting in the demethylation of $\mathrm{H} 3 \mathrm{~K} 4 \mathrm{me} 3$ and H3K36me2 and transcription repression of genes; however, BCL-6 mutation may impair the recruitment of JHDM1B to chromatin, resulted in increased methylation levels of H3K4 and H3K36 (133). Abnormal histone methylation due to BCOR mutation may affect BCL-6 binding to the AP-2a promoter, causing aberrant activation of gene and resulting in the in occurrence of oculo-facio-cardio-dental (OFCD) syndrome, which is a rare genetic disorder characterized by teeth with extremely long roots, and craniofacial, eye and congenital cardiac abnormalities include septal defect and mitral valve defect abnormalities (133-135). On the whole, it was identified that BCOR mutation affected heart development and AP- $2 \alpha$ played a role in congenial heart defects associated with OFCD patients, and indicated that BCOR may be a novel target for diagnostic and treatment strategies of OFCD syndrome.

\section{H3K9 methylation and CHD}

G9 $a$ and GLP. G9a and GLP are known as major H3K9 monoand di-methyltransferases and contribute to transcriptional silencing, which play critical biological roles in various cells and tissues. For example, G9a and GLP are indispensable for mouse early development; G9a or GLP knockout mice exhibit embryonic lethality around E9.5 due to severe growth defects $(38,136,137)$. In order to clarify the roles of G9a and GLP in cardiac development, Inagawa et al analyzed the phenotypes of cardiomyocyte specific GLP knockout and G9a knockdown mice, it was shown that the H3K9me2 level decreased mark- edly in the nuclei of the cardiomyocytes of these mice, and the mice exhibited neonatal lethality and severe cardiac defects characterized by atrioventricular septal defects (138). These data indicated that G9a and GLP were required for $\mathrm{H} 3 \mathrm{~K} 9 \mathrm{me} 2$ in cardiomyocytes and performed an essential role in normal morphogenesis of the atrioventricular septum through regulation of the size of the atrioventricular cushion.

Euchromatin histone methyl transferase 1 (EHMT1). EHMT1 is located on chromosome 9 and encodes Eu-HMTase1, which is a type of methyltransferase found in the region of the chromatin region. EHMT1 could specifically modify H3K9 methylation and thus inhibit the activity of related genes. Some studies have found EHMT1 mutation or deletion is the main cause of chromosome $9 q$ subtelomere deletion syndrome (9qSTDS), approximately half of affected individuals have congenital heart defects primarily characterized by atrial septal defect or ventricular septal defect $(139,140)$.

Blimp-1/PRDM. The PR/SET domain zinc-finger transcriptional repressor Blimp-1/PRDM is initially cloned as a negative regulator of key transcription factors expression and encoded by PRDM1, which contains PR/SET domain in N-terminal and $\mathrm{C} 2 \mathrm{H} 2$ zinc finger structure in C-terminal, and thus plays essential roles in primordial germ cell specification, placental, heart, and forelimb development, plasma cell differentiation, and T-cell homeostasis through regulating DNA binding, nuclear input and recruitment of histone modifying enzymes (141). Blimp-1/ PRDM causes H3K4 methylation by recruiting of histone modifying enzymes, which inhibits relevant genes expression and thus regulates the development of embryos. In the development of embryos, Blimp-1/PRDM deficiency caused serious cardiac defects including ventricular septal defect and persistent arterial trunk $(141,142)$.

Jarid2. Jarid2, also termed as Jumonji (jmj), the founding member of the Jumonji family, all of which contain the JmjC domain that generally confers histone demethylase activities, which can catalyze H3K9 methylation and function as a transcriptional repressor and to interact with other nuclear factors. Lee et al found that the Jarid2 homozygous mouse embryos show heart malformations, including ventricular septal defect, noncompaction of the ventricular wall, double-outlet right ventricle, and dilated atria; furthermore, expression of Jarid 2 in the interventricular septum, ventricular wall and outflow tract, which is correlated well with the locations of defects observed in the hearts of mutant mice. These results indicate that Jarid2 plays an important role in embryonic heart development (143). At the molecular level, Kim et al demonstrated that Jarid2 can inhibit the proliferation of cardiomyocytes, and inhibit the expression of atrial natriuretic peptide (ANP) by repressing the interaction with transcription factor Nkx2.5 and GATA4 (144). Other studies have also found that mutations or deletions of Jarid 2 could increase H3K9 and H3K36 methylation level, resulting in the abnormal expression of development-related genes and thus inducing atrial septal defect or ventricular septal defect and other cardiac defects $(145,146)$.

\section{H3K27 methylation and CHD}

Polycomb group proteins. Polycomb group proteins are key regulators of gene expression during development and differentiation, silencing genes via regulation of the chromatin structure, which act in complexes that have specific catalytic 
functions important for transcriptional repression. In mammals, 2 major Polycomb group complexes exist: polycomb repressive complex 1 (PRC1) and PRC2. Whereas PRC1 ubiquitinates histone H2A on Lys119,1 PRC2 catalyzes dimethylation and trimethylation of $\mathrm{H} 3 \mathrm{~K} 27$, generating H3K27me2/3 (147). Weston et al pointed out that Rae 28 protein, the core component of PRC1, which made PRC1 bind to H3K27me3 and then formed chromatin tight structure to prevent the occurrence of transcription. Rae28 mutation or deletion mice tend to perform bone dysplasia and heart development defects (148). However, Ezh2, the major histone methyltransferase of PRC2, trimethylates H3K27 and is essential for embryonic development (149). Delgado-Olguín et al have shown that Ezh2 stabilizes cardiac gene expression and prevents cardiac pathology, but Ezh2 deletion in cardiac progenitors causes postnatal myocardial pathology and destabilizes cardiac gene expression, which suggests that Ezh2 is essential for stable postnatal heart gene expression and homeostasis (150). Furthermore, Chen et al demonstrated that a variety of cardiovascular structural malformations were observed in the Ezh2 mutant mice, including double outlet right ventricle, persistent truncus arteriosus, membranous and muscular ventricular septal defects, atrial septal defects, atrioventricular canal defects and enlarged aortic valves, which defined an indispensible role of Ezh2 in normal cardiovascular development (151).

Ubiquitously transcribed tetratricopeptide repeat, $X$ chromosome (UTX). Histone demethylase UTX, also known as KDM6A, that specifically targets the repressive $\mathrm{H} 3 \mathrm{~K} 27 \mathrm{me} 3$ modification plays an important role in the activation of 'bivalent' genes in response to specific developmental cues. Welstead et al showed that UTX-deficient embryos had reduced somite counts, neural tube closure defects and heart malformation that presented between E9.5 and E13.5 (152). Other studies have also found that UTX-deficient ESCs failed to develop heart-like rhythmic contractions under a cardiac differentiation condition; UTX deficient mice exhibited severe defects in heart development and embryonic lethality; these data establish that UTX is required for heart development acts as a critical switch to activate the cardiac developmental program $(153,154)$.

Jumonji domain-containing protein 3 (Jmjd3). Jmjd3 (KDM6B), another H3K27 demethylase, functions redundantly with UTX. Jmjd3 is induced and participates in Hox gene expression during development, neuronal differentiation and inflammation, and recent data suggest that Jmjd3 inhibits reprogramming by inducing cellular senescence (155). Jmjd3 deficient mice showed embryonic lethality before E6.5, suggesting a crucial role of Jmjd3 in early embryonic development $(156,157)$. The ablation of Jmjd 3 in mouse ESCs impaired mesoderm and subsequent endothelial and cardiac differentiation. These results clarify that Jmjd3 is necessary for mesoderm differentiation and cardiovascular lineage commitment (158).

\section{H3K36 methylation and CHD}

Nuclear receptor SET domain containing gene 1 (NSD1). NSD1 is a structure containing the SET domain proteins, with specific H3K36 and H4K20 methyltransferase activity, which is associated with Sotos syndrome by haploinsufficiency $(159,160)$. A very frequent feature among Sotos syndrome patients with intragenic mutations was the presence of congenital heart defects or heart conduction defects, including isolated atrial septal defect, atrial septal defect in association with other structural abnormalities (patent ductus arteriosus; aortic valve dysplasia; ventricular septal defect and aortic coarctation) (161). This evidence indicates that NSD1 may be a cause of a higher prevalence of congenital heart defect in Sotos syndrome patients, which may be a novel target of diagnosis and treatment strategy for Sotos syndrome.

Wolf-Hirschhorn syndrome candidate 1 (WHSC1). WHSC1 contains AWS-SET-PostSET domain structure with methyltransferase activity, is encoded by Wolf-Hirschhorn syndrome related regional gene, is homologous with $\mathrm{H} 3 \mathrm{~K} 36$ specific methyltransferase Set2 in yeast, which can make H3K36 mono- di-, tri-methylated. WHSC1 regulates the expression of related genes through interaction with other transcription factors such as Nkx2.5, in embryonic heart, WHSC1 is found to interact with $\mathrm{Nkx} 2.5$ to repress Pdgfra expression (162). Loss of WHSC1 resulted in reduction of $\mathrm{H} 3 \mathrm{~K} 36 \mathrm{me} 3$ at the Pdgfra locus and upregulation of Pdgfra. Loss-of-WHSC1 mice are perinatal lethal with significant growth retardation and die within 10 days after birth. Deletion of a critical region of human chromosome $4 q 16.3$ containing WSHC1 gene is associated with craniofacial malformations, growth retardation, learning disability and congenital heart defects. WHSC1-null mice display a variety of atrial and ventricular septal defects that manifest those in Wolf-Hirschhorn sydrome patients (163).

Jumonji C domain-containing 5 (Jmjd5). Jmjd5 is a histone demethylase that specifically removes methyl moieties from dimethylated H3K36 and exerts a pro-proliferative effect on a large of cells. Strong Jmjd5 expression was observed only in the yolk sac at E8.5, Jmjd5 was robustly expressed in E10.5 embryos at several sites, including the heart and eye, which indicated that Jmjd5 may play an important role in heart and eye development. Jmjd5 deficiency mice embryos showed delayed development already at E8.5, embryonic lethal around E10 and were actively resorbed at E10.5 (164,165). Collectively, these data indicate that Jmjd5 is essential during embryonal development including heart development.

H3K79 methylation and CHD. H3K79 methylation is related to gene activation and DNA damage repair. Histone methylation occurs at H3K79 is catalyzed by yeast disruptor of telomeric silencing (DOT1) and its mammalian homolog, DOT1L. DOT1 is a kind of evolutionary highly conservative histone methyltransferase, which does not contain the SET domain structure, can be specific to different methylation levels in the H3K79. Compared with other histone lysine methylation, in yeast, DOT1 activity is positively regulated during transcription elongation through Rad6-Bre1 mono-ubiquitination of H2B (166). Recently, loss-of-function experiments revealed a critical role of DOT1L during mouse embryogenesis, as germline Dot1L knockout caused lethality at E10.5 with growth impairment, yolk sac angiogenesis defects, and cardiac dilation (167). In addition, cardiac-specific knockout of DOT1L resulted in increased mortality rate with chamber dilation, increased cardiomyocyte cell death, systolic dysfunction and conduction abnormalities (168). These phenotypes mimic those exhibited in patients with dilated cardiomyopathy. Interestingly, Nguyen et al demonstrated that DOT1L is downregulated in idiopathic DCM patient samples compared with normal controls (168). Therefore, the above studies not only establish 
a critical role for DOT1L-mediated H3K79 methylation in cardiomyocyte function, but also open new avenues for the diagnosis and treatment of CHD.

H4K2O methylation and CHD. H4K20 can be catalyzed to different forms of monomethylation, dimethylation and trimethylation, PR-SET7 can only single methylate H4K20, but double and triple methylation of H4K20 are catalyzed by two other methyltransferases SUV4-20h1 and SUV4-20h2 (169). It is shown that H4K20 methylation is related to transcription silence, H4K20me3 plays a vital role in the regulation of DNA damage but not directly regulates the expression of genes (170). In addition, Tatton-Brown and Rahman have found that NSD1 is a protein containing the SET domain structure, which with specific H4K20 and H3K36 methyltransferase activity (171). NSD1 mutation or deficiency is the main cause of Sotos syndrome which with a high incidence of CHD characterized by ventricular septal defect, atrial septal defects and patent ductus arteriosus $(159,160)$.

\section{Conclusion and prospection}

Histone modification is the important content of epigenetics, which is not only showed as directly regulating gene expressions, but also influencing gene activity through DNA modification because of its intimate touching with DNA. However, single histone modification usually cannot come into effect individually, and it determines together the gene expression of genome through collaborative effect of multiple histone modifications; but, yet so far, about the mechanism of histone modification, especially the specific mechanism of regulation of histone modification is not quite clear. Therefore, although the histone lysine methylation modification is related to CHD, further intensive research is still needed to illuminate relationship at the level of molecule. At the same time, besides the genetic factors of CHD pathogenesis, there still exist outer environmental factors, so that the complexity of diagnosing and treatment of diseases has been increased. However, it is clear that the comprehensive and meticulous investigation of histone lysine methylation modifications may provide new insight and understaning into the exploration of CHD pathogenesis and targeted prevention.

\section{Acknowledgements}

We apologize to the colleagues whose studies could not be cited in this review due to space limitations. This study was supported by grants from the Fundamental Research Funds for the Central Universities (no. 2042016kf0074), the National Natural Science Foundation of China (no. 81170307) and Specialized Research Fund for the Doctoral Program of Higher Education (no. 20120141110013).

\section{References}

1. Campos CM, Zanardo EA, Dutra RL, Kulikowski LD and Kim CA: Investigation of copy number variation in children with conotruncal heart defects. Arq Bras Cardiol 104: 24-31, 2015.

2. Barros TL, Dias MdeJ and Nina RV: Congenital cardiac disease in childhood $\mathrm{x}$ socioeconomic conditions: A relationship to be considered in public health? Rev Bras Cir Cardiovasc 29: 448-454, 2014
3. Steffensen TS and Spicer DE: Congenital coronary artery anomalies for the pathologist. Fetal Pediatr Pathol 33: 268-288, 2014.

4. Sanchez-Castro M, Pichon O, Briand A, Poulain D, Gournay V, David A and Le Caignec C: Disruption of the SEMA3D gene in a patient with congenital heart defects. Hum Mutat 36: 30-33, 2015.

5. Vecoli C, Pulignani S, Foffa I and Andreassi MG: Congenital heart disease: The crossroads of genetics, epigenetics and environment. Curr Genomics 15: 390-399, 2014

6. Gittenberger-de Groot AC, Calkoen EE, Poelmann RE, Bartelings MM and Jongbloed MR: Morphogenesis and molecular considerations on congenital cardiac septal defects. Ann Med 46: 640-652, 2014.

7. Wang X, Li P, Chen S, Xi L, Guo Y, Guo A and Sun K: Influence of genes and the environment in familial congenital heart defects. Mol Med Rep 9: 695-700, 2014.

8. Lalani SR and Belmont JW: Genetic basis of congenital cardiovascular malformations. Eur J Med Genet 57: 402-413, 2014.

9. Kathiriya IS, Nora EP and Bruneau BG: Investigating the transcriptional control of cardiovascular development. Circ Res 116: 700-714, 2015.

10. Meganathan K, Sotiriadou I, Natarajan K, Hescheler J and Sachinidis A: Signaling molecules, transcription growth factors and other regulators revealed from in-vivo and in-vitro models for the regulation of cardiac development. Int J Cardiol 183: 117-128, 2015.

11. Li Y, Klena NT, Gabriel GC, Liu X, Kim AJ, Lemke K, Chen Y, Chatterjee B, Devine W, Damerla RR, et al: Global genetic analysis in mice unveils central role for cilia in congenital heart disease. Nature 521: 520-524, 2015.

12. Andersen TA, Troelsen KL and Larsen LA: Of mice and men: Molecular genetics of congenital heart disease. Cell Mol Life Sci 71: 1327-1352, 2014

13. Yuan S, Zaidi S and Brueckner M: Congenital heart disease: Emerging themes linking genetics and development. Curr Opin Genet Dev 23: 352-359, 2013.

14. Serra-Juhé C, Cuscó I, Homs A, Flores R, Torán N and Pérez-Jurado LA: DNA methylation abnormalities in congenital heart disease. Epigenetics 10: 167-177, 2015.

15. Zhang QJ and Liu ZP: Histone methylations in heart development, congenital and adult heart diseases. Epigenomics 7: 321-330, 2015.

16. Chang $\mathrm{CP}$ and Bruneau BG: Epigenetics and cardiovascular development. Annu Rev Physiol 74: 41-68, 2012.

17. D'Urso A and Brickner JH: Mechanisms of epigenetic memory. Trends Genet 30: 230-236, 2014.

18. Becker PB and Workman JL: Nucleosome remodeling and epigenetics. Cold Spring Harb Perspect Biol 5: a017905, 2013.

19. Krishnakumar R and Blelloch RH: Epigenetics of cellular reprogramming. Curr Opin Genet Dev 23: 548-555, 2013.

20. Singmann P, Shem-Tov D, Wahl S, Grallert H, Fiorito G, Shin SY, Schramm K, Wolf P, Kunze S, Baran Y, et al: Characterization of whole-genome autosomal differences of DNA methylation between men and women. Epigenetics Chromatin 8: 43, 2015.

21. Ziegler-Birling C, Daujat S, Schneider R and Torres-Padilla ME: Dynamics of histone $\mathrm{H} 3$ acetylation in the nucleosome core during mouse pre-implantation development. Epigenetics 11: 553-562, 2016.

22. Dudakovic A,CamilleriET,XuF,RiesterSM,McGee-Lawrence ME, Bradley EW, Paradise CR, Lewallen EA, Thaler R, Deyle DR, et al: Epigenetic control of skeletal development by the histone methyltransferase Ezh2. J Biol Chem 290: 27604-27617, 2015.

23. Huang F, Ramakrishnan S, Pokhrel S, Pflueger C, Parnell TJ, Kasten MM, Currie SL, Bhachech N, Horikoshi M, Graves BJ, et al: Interaction of the Jhd2 $\mathrm{H} 3 \mathrm{~K} 4$ demethylase with chromatin is controlled by histone $\mathrm{H} 2 \mathrm{~A}$ surfaces and restricted by $\mathrm{H} 2 \mathrm{~B}$ ubiquitination. J Biol Chem 290: 28760-28777, 2015.

24. Wang Z, Casas-Mollano JA, Xu J, Riethoven JJ, Zhang C and Cerutti $\mathrm{H}$ : Osmotic stress induces phosphorylation of histone $\mathrm{H} 3$ at threonine 3 in pericentromeric regions of Arabidopsis thaliana. Proc Natl Acad Sci USA 112: 8487-8492, 2015.

25. Yao Y, Des Marais TL and Costa M: Chromatin memory in the development of human cancers. Gene Technol 3: 114, 2014.

26. Heo JB and Sung S: Encoding memory of winter by noncoding RNAs. Epigenetics 6: 544-547, 2011.

27. Torres IO and Fujimori DG: Functional coupling between writers, erasers and readers of histone and DNA methylation. Curr Opin Struct Biol 35: 68-75, 2015.

28. Jaworska J, Ziemka-Nalecz M and Zalewska T: Histone deacetylases 1 and 2 are required for brain development. Int J Dev Biol 59: 171-177, 2015. 
29. Carr SM, Poppy Roworth A, Chan C and La Thangue NB: Post-translational control of transcription factors: Methylation ranks highly. FEBS J 282: 4450-4465, 2015.

30. Gupta N, Madapura MP, Bhat UA and Rao MR: Mapping of posttranslational modifications of transition proteins, TP1 and TP2 and identification of protein arginine methyltransferase 4 and lysine methyltransferase 7 as methyltransferase for TP2. J Biol Chem 290: 12101-12122, 2015.

31. Binda O: On your histone mark, SET, methylate! Epigenetics 8: 457-463, 2013

32. Lesne A, Foray N, Cathala G, Forné T, Wong H and Victor JM: Chromatin fiber allostery and the epigenetic code. J Phys Condens Matter 27: 064114, 2015.

33. Zuchegna C, Aceto F, Bertoni A, Romano A, Perillo B, Laccetti P, Gottesman ME, Avvedimento EV and Porcellini A: Mechanism of retinoic acid-induced transcription: Histone code, DNA oxidation and formation of chromatin loops. Nucleic Acids Res 42: 11040-11055, 2014

34. Gayatri S and Bedford MT: Readers of histone methylarginine marks. Biochim Biophys Acta 1839: 702-710, 2014.

35. Casciello F, Windloch K, Gannon F and Lee JS: Functional role of G9a histone methyltransferase in cancer. Front Immunol 6: 487, 2015.

36. Ortega-Molina A, Boss IW, Canela A, Pan H, Jiang Y, Zhao C, Jiang M, Hu D, Agirre X, Niesvizky I, et al: The histone lysine methyltransferase KMT2D sustains a gene expression program that represses B cell lymphoma development. Nat Med 21 : $1199-1208,2015$.

37. Cho MH, Park JH, Choi HJ, Park MK, Won HY, Park YJ, Lee CH, Oh SH, Song YS, Kim HS, et al: DOT1L cooperates with the c-Myc-p300 complex to epigenetically derepress CDH1 transcription factors in breast cancer progression. Nat Commun 6 : $7821,2015$.

38. Liu N, Zhang Z, Wu H, Jiang Y, Meng L, Xiong J, Zhao Z, Zhou X, Li J, Li H, et al: Recognition of H3K9 methylation by GLP is required for efficient establishment of H3K9 methylation, rapid target gene repression, and mouse viability. Genes Dev 29: 379-393, 2015.

39. Nicetto D, Hahn M, Jung J, Schneider TD, Straub T, David R, Schotta G and Rupp RA: Suv4-20h histone methyltransferases promote neuroectodermal differentiation by silencing the pluripotency-associated Oct-25 gene. PLoS Genet 9: e1003188, 2013.

40. Maes T, Mascaró C, Ortega A,Lunardi S, Ciceri F, Somervaille TC and Buesa C: KDM1 histone lysine demethylases as targets for treatments of oncological and neurodegenerative disease. Epigenomics 7: 609-626, 2015.

41. Belakavadi M, Dell J, Grover GJ and Fondell JD: Thyroid hormone suppression of $\beta$-amyloid precursor protein gene expression in the brain involves multiple epigenetic regulatory events. Mol Cell Endocrinol 339: 72-80, 2011.

42. Stein AB, Goonewardena SN, Jones TA, Prusick PJ, Bazzi AA, Belyavskaya JM, McCoskey MM and Dandar RA: The PTIP-associated histone methyltransferase complex prevents stress-induced maladaptive cardiac remodeling. PLoS One 10: e0127839, 2015.

43. Mathiyalagan P, Keating ST, Du XJ and El-Osta A: Chromatin modifications remodel cardiac gene expression. Cardiovasc Res 103: 7-16, 2014

44. Hohl M, Wagner M, Reil JC, Müller SA, Tauchnitz M, Zimmer AM, Lehmann LH, Thiel G, Böhm M, Backs J, et al: HDAC4 controls histone methylation in response to elevated cardiac load. J Clin Invest 123: 1359-1370, 2013.

45. Bingham AJ, Ooi L, Kozera L, White E and Wood IC: The repressor element 1-silencing transcription factor regulates heartspecific gene expression using multiple chromatin-modifying complexes. Mol Cell Biol 27: 4082-4092, 2007.

46. Cabrera JR, Olcese U and Horabin JI: A balancing act: Heterochromatin protein 1a and the polycomb group coordinate their levels to silence chromatin in Drosophila. Epigenetics Chromatin 8: 17, 2015.

47. Sautel CF, Cannella D, Bastien O, Kieffer S, Aldebert D, Garin J, Tardieux I, Belrhali H and Hakimi MA: SET8-mediated methylations of histone $\mathrm{H} 4$ lysine 20 mark silent heterochromatic domains in apicomplexan genomes. Mol Cell Biol 27: 5711-5724, 2007.

48. Guo X, Wang L, Li J, Ding Z, Xiao J, Yin X, He S, Shi P, Dong L, Li G, et al: Structural insight into autoinhibition and histone H3-induced activation of DNMT3A. Nature 517: 640-644, 2015.

49. Minkovsky A, Sahakyan A, Rankin-Gee E, Bonora G, Patel S and Plath K: The Mbd1-Atf7ip-Setdb1 pathway contributes to the maintenance of $\mathrm{X}$ chromosome inactivation. Epigenetics Chromatin 7: 12, 2014.
50. Simon MD,Pinter SF, Fang R, SarmaK, Rutenberg-Schoenberg M Bowman SK, Kesner BA, Maier VK, Kingston RE and Lee JT: High-resolution Xist binding maps reveal two-step spreading during X-chromosome inactivation. Nature 504: 465-469, 2013.

51. Wang J, Telese F, Tan Y, Li W, Jin C, He X, Basnet H, Ma Q, Merkurjev D, Zhu X, et al: LSD1n is an H4K20 demethylase regulating memory formation via transcriptional elongation control. Nat Neurosci 18: 1256-1264, 2015.

52. Sen P, Dang W, Donahue G, Dai J, Dorsey J, Cao X, Liu W, Cao K, Perry R, Lee JY, et al: H3K36 methylation promotes longevity by enhancing transcriptional fidelity. Genes Dev 29: 1362-1376, 2015.

53. Kang SC, Kim SK, Chai JC, Kim SH, Won KJ, Lee YS, Jung KH and Chai YG: Transcriptomic Profiling and H3K27me3 Distribution reveal both demethylase-dependent and independent regulation of developmental gene transcription in cell differentiation. PLoS One 10: e0135276, 2015.

54. Copur Ö and Müller J: The histone H3-K27 demethylase Utx regulates HOX gene expression in Drosophila in a temporally restricted manner. Development 140: 3478-3485, 2013.

55. You L, Nie J, Sun WJ, Zheng ZQ and Yang XJ: Lysine acetylation: Enzymes, bromodomains and links to different diseases. Essays Biochem 52: 1-12, 2012.

56. Migliori V, Phalke S, Bezzi M and Guccione E: Arginine/lysinemethyl/methyl switches: Biochemical role of histone arginine methylation in transcriptional regulation. Epigenomics 2: 119-137, 2010.

57. Davie JK and Dent SY: Transcriptional control: An activating role for arginine methylation. Curr Biol 12: R59-R61, 2002.

58. Tessarz P and Kouzarides T: Histone core modifications regulating nucleosome structure and dynamics. Nat Rev Mol Cell Biol 15: 703-708, 2014.

59. Strahl BD, Briggs SD, Brame CJ, Caldwell JA, Koh SS Ma H, Cook RG, Shabanowitz J, Hunt DF, Stallcup MR, et al: Methylation of histone $\mathrm{H} 4$ at arginine 3 occurs in vivo and is mediated by the nuclear receptor coactivator PRMT1. Curr Biol 11: 996-1000, 2001.

60. Wang H, Huang ZQ, Xia L, Feng Q, Erdjument-Bromage $H$, Strahl BD, Briggs SD, Allis CD, Wong J, Tempst P, et al: Methylation of histone $\mathrm{H} 4$ at arginine 3 facilitating transcriptional activation by nuclear hormone receptor. Science 293 853-857, 2001.

61. Schurter BT, Koh SS, Chen D, Bunick GJ, Harp JM, Hanson BL, Henschen-Edman A, Mackay DR, Stallcup MR and Aswad DW: Methylation of histone $\mathrm{H} 3$ by coactivator-associated arginine methyltransferase 1. Biochemistry 40: 5747-5756, 2001.

62. Aoshima K, Inoue E, Sawa H and Okada Y: Paternal H3K4 methylation is required for minor zygotic gene activation and early mouse embryonic development. EMBO Rep 16: 803-812, 2015.

63. Shinsky SA, Monteith KE, Viggiano S and Cosgrove MS: Biochemical reconstitution and phylogenetic comparison of human SET1 family core complexes involved in histone methylation. J Biol Chem 290: 6361-6375, 2015.

64. Chen CW, Koche RP, Sinha AU, Deshpande AJ, Zhu N, Eng R, Doench JG, Xu H, Chu SH, Qi J, et al: DOT1L inhibits SIRT1-mediated epigenetic silencing to maintain leukemic gene expression in MLL-rearranged leukemia. Nat Med 21: 335-343, 2015.

65. Jiao L and Liu X: Structural basis of histone H3K27 trimethylation by an active polycomb repressive complex 2 . Science 350 aac4383, 2015.

66. Foda BM and Singh U: Dimethylated H3K27 is a repressive epigenetic histone mark in the protist Entamoeba histolytica and is significantly enriched in genes silenced via the RNAi pathway. J Biol Chem 290: 21114-21130, 2015.

67. Vieira FQ, Costa-Pinheiro P, Almeida-Rios D, Graça I, Monteiro-Reis S, Simões-Sousa S, Carneiro I, Sousa EJ, Godinho MI, Baltazar F, et al: SMYD3 contributes to a more aggressive phenotype of prostate cancer and targets Cyclin D2 through H4K20me3. Oncotarget 6: 13644-13657, 2015.

68. Bierhoff H, Dammert MA, Brocks D, Dambacher S, Schotta G and Grummt I: Quiescence-induced LncRNAs trigger H4K20 trimethylation and transcriptional silencing. Mol Cell 54: 675-682, 2014

69. Zhang X, Tanaka K, Yan J, Li J, Peng D, Jiang Y, Yang Z, Barton MC, Wen H and Shi X: Regulation of estrogen receptor $\alpha$ by histone methyltransferase SMYD2-mediated protein methylation. Proc Natl Acad Sci USA 110: 17284-17289, 2013.

70. Hossain MA, Chung C, Pradhan SK and Johnson TL: The yeast cap binding complex modulates transcription factor recruitment and establishes proper histone H3K36 trimethylation during active transcription. Mol Cell Biol 33: 785-799, 2013. 
71. Ontoso D, Acosta I, van Leeuwen F, Freire R and San-Segundo PA Dot1-dependent histone H3K79 methylation promotes activation of the Mek1 meiotic checkpoint effector kinase by regulating the Hop1 adaptor. PLoS Genet 9: e1003262, 2013.

72. Kim SK, Jung I, Lee H, Kang K, Kim M, Jeong K, Kwon CS, Han YM, Kim YS, Kim D, et al: Human histone H3K79 methyltransferase DOT1L protein [corrected] binds actively transcribing RNA polymerase II to regulate gene expression. J Biol Chem 287: 39698-39709, 2012.

73. Zhao XX, Zhang YB, Ni PL, Wu ZL, Yan YC and Li YP: Protein arginine methyltransferase 6 (Prmt6) is essential for early zebrafish development through the direct suppression of Gadd45alphaa stress sensor gene. J Biol Chem 291: 402-412, 2016.

74. Feng Y, Hadjikyriacou A and Clarke SG: Substrate specificity of human protein arginine methyltransferase 7 (PRMT7) The importance of acidic residues in the double E loop. J Biol Chem 289: 32604-32616, 2014

75. Su X, Zhu G, Ding X, Lee SY, Dou Y, Zhu B, Wu W and Li H: Molecular basis underlying histone $\mathrm{H} 3$ lysine-arginine methylation pattern readout by Spin/Ssty repeats of Spindlin1. Genes Dev 28: 622-636, 2014

76. Nguyen HC, Wang M, Salsburg A and Knuckley B: Development of a plate-based screening assay to investigate the dubstrate dpecificity of the PRMT gamily of rnzymes. ACS Comb Sci 17: 500-505, 2015

77. Tini M, Naeem $\mathrm{H}$ and Torchia J: Biochemical analysis of arginine methylation in transcription. Methods Mol Biol 523: 235-247, 2009.

78. Del Rizzo PA and Trievel RC: Substrate and product specificities of SET domain methyltransferases. Epigenetics 6: 1059-1067, 2011.

79. Couture JF and Trievel RC: Histone-modifying enzymes: Encrypting an enigmatic epigenetic code. Curr Opin Struct Biol 16: 753-760, 2006

80. Spellmon N, Holcomb J, Trescott L, Sirinupong N and Yang Z: Structure and function of SET and MYND domain-containing proteins. Int J Mol Sci 16: 1406-1428, 2015.

81. Anand R and Marmorstein R: Structure and mechanism of lysinespecific demethylase enzymes. J Biol Chem 282: 35425-35429, 2007.

82. Tsukada Y and Zhang Y: Purification of histone demethylases from HeLa cells. Methods 40: 318-326, 2006.

83. Liu L, Jin G and Zhou X: Modeling the relationship of epigenetic modifications to transcription factor binding. Nucleic Acids Res 43: 3873-3885, 2015.

84. Bai H, Li Y, Gao H, Dong Y, Han P and Yu H: Histone methyltransferase SMYD3 regulates the expression of transcriptional factors during bovine oocyte maturation and early embryonic development. Cytotechnology 68: 849-859, 2016

85. Kim JD, Kim E, Koun S, Ham HJ, Rhee M, Kim MJ and Huh TL: Proper activity of histone $\mathrm{H} 3$ lysine 4 (H3K4) methyltransferase is required for morphogenesis during zebrafish cardiogenesis. Mol Cells 38: 580-586, 2015.

86. Martinez SR, Gay MS and Zhang L: Epigenetic mechanisms in heart development and disease. Drug Discov Today 20: 799-811, 2015.

87. Dorn GW II and Matkovich SJ: Epitranscriptional regulation of cardiovascular development and disease. J Physiol 593 1799-1808, 2015

88. Zhao W, Liu L, Pan B, Xu Y, Zhu J, Nan C, Huang X and Tian J: Epigenetic regulation of cardiac myofibril gene expression during heart development. Cardiovasc Toxicol 15: 203-209, 2015.

89. Park CY, Pierce SA, von Drehle M, Ivey KN, Morgan JA, Blau HM and Srivastava D: skNAC, a Smyd1-interacting transcription factor, is involved in cardiac development and skeletal muscle growth and regeneration. Proc Natl Acad Sci USA 107: 20750-20755, 2010.

90. Drake KM, Comhair SA, Erzurum SC, Tuder RM and Aldred MA Endothelial chromosome 13 deletion in congenital heart diseaseassociated pulmonary arterial hypertension dysregulates SMAD9 signaling. Am J Respir Crit Care Med 191: 850-854, 2015.

91. Geng J, Picker J, Zheng Z, Zhang X, Wang J, Hisama F, Brown DW, Mullen MP, Harris D, Stoler J, et al: Chromosome microarray testing for patients with congenital heart defects reveals novel disease causing loci and high diagnostic yield. BMC Genomics 15: 1127, 2014.

92. Zaidi S, Choi M, Wakimoto H, Ma L, Jiang J, Overton JD, Romano-Adesman A, Bjornson RD, Breitbart RE, Brown KK, et al: De novo mutations in histone-modifying genes in congenital heart disease. Nature 498: 220-223, 2013.
93. Ozanne SE and Constância M: Mechanisms of disease: The developmental origins of disease and the role of the epigenotype. Nat Clin Pract Endocrinol Metab 3: 539-546, 2007.

94. Wang QT: Epigenetic regulation of cardiac development and function by polycomb group and trithorax group proteins. Dev Dyn 241: 1021-1033, 2012

95. Geisler SJ and Paro R: Trithorax and Polycomb group-dependent regulation: A tale of opposing activities. Development 142 2876-2887, 2015.

96. Wan X, Liu L, Ding X, Zhou P, Yuan X, Zhou Z, Hu P, Zhou H, Li Q, Zhang S, et al: M112 controls cardiac lineage differentiation of mouse embryonic stem cells by promoting H3K4me3 deposition at cardiac-specific genes. Stem Cell Rev 10: 643-652, 2014

97. Tan X, Rotllant J, Li H, De Deyne P and Du SJ: SmyD1, a histone methyltransferase, is required for myofibril organization and muscle contraction in zebrafish embryos. Proc Natl Acad Sci USA 103: 2713-2718, 2006.

98. Du SJ, Tan X and Zhang J: SMYD proteins: Key regulators in skeletal and cardiac muscle development and function. Anat Rec (Hoboken) 297: 1650-1662, 2014.

99. Rasmussen TL, Ma Y, Park CY, Harriss J, Pierce SA, Dekker JD, Valenzuela N, Srivastava D, Schwartz RJ, Stewart MD, et al: Smyd1 facilitates heart development by antagonizing oxidative and ER stress responses. PLoS One 10: e0121765, 2015

100. Diehl F, Brown MA, van Amerongen MJ, Novoyatleva T, Wietelmann A, Harriss J, Ferrazzi F, Böttger T, Harvey RP, Tucker PW, et al: Cardiac deletion of Smyd2 is dispensable for mouse heart development. PLoS One 5: e9748, 2010.

101. Fujii T, Tsunesumi S, Yamaguchi K, Watanabe S and Furukawa Y: Smyd3 is required for the development of cardiac and skeletal muscle in zebrafish. PLoS One 6: e23491, 2011.

102. Papaioannou VE: The T-box gene family: Emerging roles in development, stem cells and cancer. Development 141 3819-3833, 2014.

103. Greulich F, Rudat C and Kispert A: Mechanisms of T-box gene function in the developing heart. Cardiovasc Res 91: 212-222, 2011

104. Chen L,Fulcoli FG, Ferrentino R, Martucciello S, Illingworth EA and Baldini A: Transcriptional control in cardiac progenitors: Tbx1 interacts with the BAF chromatin remodeling complex and regulates Wnt5a. PLoS Genet 8: e1002571, 2012.

105. Caprio C and Baldini A: p53 Suppression partially rescues the mutant phenotype in mouse models of DiGeorge syndrome. Proc Natl Acad Sci USA 111: 13385-13390, 2014.

106. Pan Y, Wang ZG, Liu XY, Zhao H, Zhou N, Zheng GF, Qiu XB Li RG, Yuan F, Shi HY, et al: A novel TBX1 loss-of-function mutation associated with congenital heart disease. Pediatr Cardiol 36: 1400-1410, 2015.

107. Sedletcaia A and Evans T: Heart chamber size in zebrafish is regulated redundantly by duplicated tbx 2 genes. Dev Dyn 240 1548-1557, 2011

108. Pang S, Liu Y, Zhao Z, Huang W, Chen D and Yan B: Novel and functional sequence variants within the TBX2 gene promoter in ventricular septal defects. Biochimie 95: 1807-1809, 2013.

109. van Weerd JH, Badi I, van den Boogaard M, Stefanovic S, van de Werken HJ, Gomez-Velazquez M, Badia-Careaga C, Manzanares M, de Laat W, Barnett P, et al: A large permissive regulatory domain exclusively controls $\mathrm{Tbx} 3$ expression in the cardiac conduction system. Circ Res 115: 432-441, 2014.

110. Hatcher CJ, Diman NY, Kim MS, Pennisi D, Song Y, Goldstein MM, Mikawa T and Basson CT: A role for Tbx5 in proepicardial cell migration during cardiogenesis. Physiol Genomics 18: 129-140, 2004.

111. Diman NY, Brooks G, Kruithof BP, Elemento O, Seidman JG, Seidman CE, Basson CT and Hatcher CJ: Tbx 5 is required for avian and Mammalian epicardial formation and coronary vasculogenesis. Circ Res 115: 834-844, 2014.

112. Zhou L, Liu J, Olson P, Zhang K, Wynne J and Xie L: Tbx 5 and Osrl interact to regulate posterior second heart field cell cycle progression for cardiac septation. J Mol Cell Cardiol 85: 1-12, 2015

113. Al-Qattan MM and Abou Al-Shaar H: Molecular basis of the clinical features of Holt-Oram syndrome resulting from missense and extended protein mutations of the TBX5 gene as well as TBX5 intragenic duplications. Gene 560: 129-136, 2015.

114. Kimura M, Kikuchi A, Ichinoi N and Kure S: Novel TBX5 duplication in a Japanese family with Holt-Oram syndrome. Pediatr Cardiol 36: 244-247, 2015

115. Wu SP, Dong XR, Regan JN, Su C and Majesky MW: Tbx 18 regulates development of the epicardium and coronary vessels. Dev Biol 383: 307-320, 2013. 
116. Cai X, Zhang W, Hu J, Zhang L, Sultana N, Wu B, Cai W, Zhou B and Cai CL: Tbx20 acts upstream of Wnt signaling to regulate endocardial cushion formation and valve remodeling during mouse cardiogenesis. Development 140: 3176-3187, 2013.

117. Shen T, Aneas I, Sakabe N, Dirschinger RJ, Wang G, Smemo S, Westlund JM, Cheng H, Dalton N, Gu Y, et al: Tbx20 regulates a genetic program essential to adult mouse cardiomyocyte function. J Clin Invest 121: 4640-4654, 2011.

118. Zhang W, Chen H, Wang Y, Yong W, Zhu W, Liu Y, Wagner GR, Payne RM, Field LJ, Xin H, et al: Tbx20 transcription factor is a downstream mediator for bone morphogenetic protein-10 in regulating cardiac ventricular wall development and function. J Biol Chem 286: 36820-36829, 2011

119. Kirk EP, Sunde M, Costa MW, Rankin SA, Wolstein O, Castro ML, Butler TL, Hyun C, Guo G, Otway R, et al: Mutations in cardiac T-box factor gene TBX20 are associated with diverse cardiac pathologies, including defects of septation and valvulogenesis and cardiomyopathy. Am J Hum Genet 81: 280-291, 2007.

120. Ishizaka A, Mizutani T, Kobayashi K, Tando T, Sakurai K, Fujiwara T and Iba H: Double plant homeodomain (PHD) finger proteins DPF3a and $-3 b$ are required as transcriptional co-activators in SWI/SNF complex-dependent activation of NF- $\kappa$ B RelA/p50 heterodimer. J Biol Chem 287: 11924-11933, 2012.

121.Lange M, Kaynak B, Forster UB, Tönjes M, Fischer JJ, Grimm C, Schlesinger J, Just S, Dunkel I, Krueger T, et al: Regulation of muscle development by DPF3, a novel histone acetylation and methylation reader of the BAF chromatin remodeling complex. Genes Dev 22: 2370-2384, 2008.

122.Liu Y, Huang Y, Fan J and Zhu GZ: PITX2 associates with PTIP-containing histone $\mathrm{H} 3$ lysine 4 methyltransferase complex. Biochem Biophys Res Commun 444: 634-637, 2014.

123. Kim D, Patel SR, Xiao H and Dressler GR: The role of PTIP in maintaining embryonic stem cell pluripotency. Stem Cells 27: 1516-1523, 2009.

124. Fang M, Ren H, Liu J, Cadigan KM, Patel SR and Dressler GR: Drosophila ptip is essential for anterior/posterior patterning in development and interacts with the PcG and trxG pathways. Development 136: 1929-1938, 2009.

125. Callen E, Faryabi RB, Luckey M, Hao B, Daniel JA, Yang W, Sun HW, Dressler G, Peng W, Chi H, et al: The DNA damageand transcription-associated protein paxipl controls thymocyte development and emigration. Immunity 37: 971-985, 2012

126. Daniel JA, Santos MA, Wang Z, Zang C, Schwab KR, Jankovic M, Filsuf D, Chen HT, Gazumyan A, Yamane A, et al: PTIP promotes chromatin changes critical for immunoglobulin class switch recombination. Science 329: 917-923, 2010.

127. Stein AB, Jones TA, Herron TJ, Patel SR, Day SM, Noujaim SF Milstein ML, Klos M, Furspan PB, Jalife J, et al: Loss of H3K4 methylation destabilizes gene expression patterns and physiological functions in adult murine cardiomyocytes. J Clin Invest 121: 2641-2650, 2011

128. Tao Y, Neppl RL, Huang ZP, Chen J, Tang RH, Cao R, Zhang Y, Jin SW and Wang DZ: The histone methyltransferase Set7/9 promotes myoblast differentiation and myofibril assembly. J Cell Biol 194: 551-565, 2011.

129. Nicholson TB and Chen T: LSD1 demethylates histone and nonhistone proteins. Epigenetics 4: 129-132, 2009.

130. He Y, Tang D, Cai C, Chai R and Li H: LSD1 is required for hair cell regeneration in zebrafish. Mol Neurobiol 53: 2421-2434 2016.

131.van Riel B, Pakozdi T, Brouwer R, Monteiro R, Tuladhar K, Franke V, Bryne JC, Jorna R, Rijkers EJ, van Ijcken W, et al: A novel complex, RUNX1-MYEF2, represses hematopoietic genes in erythroid cells. Mol Cell Biol 32: 3814-3822, 2012.

132. Nicholson TB, Singh AK, Su H, Hevi S, Wang J, Bajko J, Li M, Valdez R, Goetschkes M, Capodieci P, et al: A hypomorphic lsd1 allele results in heart development defects in mice. PLoS One 8: e60913, 2013.

133. Fan Z, Yamaza T, Lee JS, Yu J, Wang S, Fan G, Shi S and Wang CY: BCOR regulates mesenchymal stem cell function by epigenetic mechanisms. Nat Cell Biol 11: 1002-1009, 2009.

134. Hilton E, Johnston J, Whalen S, Okamoto N, Hatsukawa Y, Nishio J, Kohara H, Hirano Y, Mizuno S, Torii C, et al: BCOR analysis in patients with OFCD and Lenz microphthalmia syndromes, mental retardation with ocular anomalies, and cardiac laterality defects. Eur J Hum Genet 17: 1325-1335, 2009.
135. Di Stefano C, Lombardo B, Fabbricatore C, Munno C, Caliendo I, Gallo F and Pastore L: Oculo-facio-cardio-dental (OFCD) syndrome: The first Italian case of BCOR and co-occurring OTC gene deletion. Gene 559: 203-206, 2015.

136. Huang XJ, Ma X, Wang X, Zhou X, Li J, Sun SC and Liu H: Involvement of G9A-like protein (GLP) in the development of mouse preimplantation embryos in vitro. Reprod Fertil Dev: May 18, 2015 (Epub ahead of print). doi: 10.1071/RD14341.

137. Tachibana M, Ueda J, Fukuda M, Takeda N, Ohta T, Iwanari H, Sakihama T, Kodama T, Hamakubo T and Shinkai Y: Histone methyltransferases G9a and GLP form heteromeric complexes and are both crucial for methylation of euchromatin at H3-K9. Genes Dev 19: 815-826, 2005.

138. Inagawa M, Nakajima K, Makino T, Ogawa S, Kojima M, Ito S, Ikenishi A, Hayashi T, Schwartz RJ, Nakamura K, et al: Histone H3 lysine 9 methyltransferases, G9a and GLP are essential for cardiac morphogenesis. Mech Dev 130: 519-531, 2013.

139. Kleefstra T, van Zelst-Stams WA, Nillesen WM, Cormier-Daire V, Houge G, Foulds N, van Dooren M, Willemsen MH, Pfundt R, Turner A, et al: Further clinical and molecular delineation of the $9 \mathrm{q}$ subtelomeric deletion syndrome supports a major contribution of EHMT1 haploinsufficiency to the core phenotype. J Med Genet 46: 598-606, 2009.

140. Stewart DR and Kleefstra T: The chromosome 9q subtelomere deletion syndrome. Am J Med Genet C Semin Med Genet 145C: 383-392, 2007.

141. Bikoff EK, Morgan MA and Robertson EJ: An expanding job description for Blimp-1/PRDM1. Curr Opin Genet Dev 19: 379-385, 2009

142. Morgan MA, Mould AW, Li L, Robertson EJ and Bikoff EK: Alternative splicing regulates Prdm1/Blimp-1 DNA binding activities and corepressor interactions. Mol Cell Biol 32: 3403-3413, 2012.

143. Lee Y, Song AJ, Baker R, Micales B, Conway SJ and Lyons GE: Jumonji, a nuclear protein that is necessary for normal heart development. Circ Res 86: 932-938, 2000.

144. Kim TG, Chen J, Sadoshima J and Lee Y: Jumonji represses atrial natriuretic factor gene expression by inhibiting transcriptional activities of cardiac transcription factors. Mol Cell Biol 24: 10151-10160, 2004.

145. Mysliwiec MR, Carlson CD, Tietjen J, Hung H, Ansari AZ and Lee Y: Jarid2 (Jumonji, AT rich interactive domain 2) regulates NOTCH1 expression via histone modification in the developing heart. J Biol Chem 287: 1235-1241, 2012.

146. Mysliwiec MR, Bresnick EH and Lee Y: Endothelial Jarid2/Jumonji is required for normal cardiac development and proper Notch1 expression. J Biol Chem 286: 17193-17204, 2011.

147. Dobreva G and Braun T: When silence is broken: Polycomb group proteins in heart development. Circ Res 110: 372-374, 2012.

148. Weston AD, Ozolins TR and Brown NA: Thoracic skeletal defects and cardiac malformations: A common epigenetic link? Birth Defects Res C Embryo Today 78: 354-370, 2006

149. Sanulli S, Justin N, Teissandier A, Ancelin K, Portoso M, Caron M, Michaud A, Lombard B, da Rocha ST, Offer J, et al: Jarid2 methylation via the PRC2 complex regulates H3K27me3 deposition during cell differentiation. Mol Cell 57: 769-783, 2015.

150. Delgado-Olguín P, Huang Y, Li X, Christodoulou D, Seidman CE, Seidman JG, Tarakhovsky A and Bruneau BG: Epigenetic repression of cardiac progenitor gene expression by Ezh2 is required for postnatal cardiac homeostasis. Nat Genet 44: 343-347, 2012.

151. Chen L, Ma Y, Kim EY, Yu W, Schwartz RJ, Qian L and Wang J: Conditional ablation of Ezh2 in murine hearts reveals its essential roles in endocardial cushion formation, cardiomyocyte proliferation and survival. PLoS One 7: e31005, 2012

152. Welstead GG, Creyghton MP, Bilodeau S, Cheng AW, Markoulaki S, Young RA and Jaenisch R: X-linked H3K27me3 demethylase Utx is required for embryonic development in a sex-specific manner. Proc Natl Acad Sci USA 109: 13004-13009, 2012.

153. Morales Torres C, Laugesen A and Helin K: Utx is required for proper induction of ectoderm and mesoderm during differentiation of embryonic stem cells. PLoS One 8: e60020, 2013.

154. Lee S, Lee JW and Lee SK: UTX, a histone H3-lysine 27 demethylase, acts as a critical switch to activate the cardiac developmental program. Dev Cell 22: 25-37, 2012. 
155. Agger K, Cloos PA, Christensen J, Pasini D, Rose S, Rappsilber J, Issaeva I, Canaani E, Salcini AE and Helin K: UTX and JMJD3 are histone H3K27 demethylases involved in HOX gene regulation and development. Nature 449: 731-734, 2007.

156.Li Q, Wang HY, Chepelev I, Zhu Q, Wei G, Zhao K and Wang RF: Stage-dependent and locus-specific role of histone demethylase Jumonji D3 (JMJD3) in the embryonic stages of lung development. PLoS Genet 10: e1004524, 2014

157. Burgold T, Voituron N, Caganova M, Tripathi PP, Menuet C, Tusi BK, Spreafico F, Bévengut M, Gestreau C, Buontempo S, et al: The H3K27 demethylase JMJD3 is required for maintenance of the embryonic respiratory neuronal network, neonatal breathing, and survival. Cell Rep 2: 1244-1258, 2012.

158. Ohtani K, Zhao C, Dobreva G, Manavski Y, Kluge B, Braun T, Rieger MA, Zeiher AM and Dimmeler S: Jmjd3 controls mesodermal and cardiovascular differentiation of embryonic stem cells. Circ Res 113: 856-862, 2013.

159. Chen CP, Lin CJ, Chern SR, Liu YP, Kuo YL, Chen YN, Wu PS, Town DD, Chen LF, Yang CW, et al: Prenatal diagnosis and molecular cytogenetic characterization of a $1.07-\mathrm{Mb}$ microdeletion at 5q35.2-q35.3 associated with NSD1 haploinsufficiency and Sotos syndrome. Taiwan J Obstet Gynecol 53: 583-587, 2014.

160. Park SH, Lee JE, Sohn YB and Ko JM: First identified Korean family with Sotos syndrome caused by a novel intragenic mutation in NSD1. Ann Clin Lab Sci 44: 228-231, 2014.

161. Sheth K, Moss J, Hyland S, Stinton C, Cole T and Oliver C: The behavioral characteristics of Sotos syndrome. Am J Med Genet A 167A: 2945-2956, 2015.

162. Vallaster M, Vallaster CD and Wu SM: Epigenetic mechanisms in cardiac development and disease. Acta Biochim Biophys Sin (Shanghai) 44: 92-102, 2012.
163. Nimura K, Ura K, Shiratori H, Ikawa M, Okabe M, Schwartz RJ and Kaneda Y: A histone $\mathrm{H} 3$ lysine 36 trimethyltransferase links Nkx2-5 to Wolf-Hirschhorn syndrome. Nature 460: 287-291, 2009.

164. Oh S and Janknecht R: Histone demethylase JMJD5 is essential for embryonic development. Biochem Biophys Res Commun 420: $61-65,2012$.

165. Kawakami E, Tokunaga A, Ozawa M, Sakamoto R and Yoshida N: The histone demethylase Fbxl11/Kdm2a plays an essential role in embryonic development by repressing cell-cycle regulators. Mech Dev 135: 31-42, 2015.

166. Mohan M, Herz HM, Takahashi YH, Lin C, Lai KC, Zhang Y, Washburn MP, Florens L and Shilatifard A: Linking H3K79 trimethylation to Wnt signaling through a novel Dot1-containing complex (DotCom). Genes Dev 24: 574-589, 2010

167. Jones B, Su H, Bhat A, Lei H, Bajko J, Hevi S, Baltus GA, Kadam S, Zhai H, Valdez R, et al: The histone H3K79 methyltransferase Dot1L is essential for mammalian development and heterochromatin structure. PLoS Genet 4: e1000190, 2008.

168. Nguyen AT, Xiao B, Neppl RL, Kallin EM, Li J, Chen T, Wang DZ, Xiao X and Zhang Y: DOT1L regulates dystrophin expression and is critical for cardiac function. Genes Dev 25: 263-274, 2011.

169. Beck DB, Burton A, Oda H,Ziegler-Birling C, Torres-Padilla ME and Reinberg D: The role of PR-Set7 in replication licensing depends on Suv4-20h. Genes Dev 26: 2580-2589, 2012.

170. Lennartsson A and Ekwall K: Histone modification patterns and epigenetic codes. Biochim Biophys Acta 1790: 863-868, 2009.

171. Tatton-Brown Kand Rahman N: Clinical features of NSD1-positive Sotos syndrome. Clin Dysmorphol 13: 199-204, 2004. 